\title{
Implementasi Human Resource Scorecard Untuk Pengukuran Kinerja Karyawan Pada Kasus Perusahaan Di Indonesia
}

\author{
Stefanus Dony Mahendra \\ stefanusdony96@gmail.com \\ Fakultas Ekonomi dan Bisnis - Program Magister Manajemen \\ Universitas Katolik Soegijapranata
}

\begin{abstract}
Human Resource Scorecard is a tool used to measure organizational performance against the strategic goals set by a company. This research aims to determine the step of application Human Resource Scorecard for Employee Performance Measurement. The method of this research consists of Planning (Explanation of Research Objectives), Research Identification (Determine of Criteria \& Selection of Research Articles), \& Selection of Primary Studies (Selection of research articles using keyword \& criteria already determined). The keyword used is "HR Scorecard". There are 2 (two) selection criteria: Inclusion criteria, which include: Research articles identified using keyword, Research articles that answer a research question, and Exclusion criteria, which includes: articles not in full text, research articles that use the HR Scorecard not to measure performance, research article with case studies on companies not located in Indonesia. The result of this study of HR Scorecard implementation are: determining business processes, calculating the weight of each perspective using Analytical Hierarchy Process, create a hierarchy problem that is used to identify complex problem into a subsystem, determine priorities, do synthesis, measuring consistency, calculate consistency ratio, checking the consistency of the hierarchy, calculate scoring system, \& give recommend for the company.
\end{abstract}

Keywords: Human Resource Scorecard; Analytical Hierarchy Process; Scoring System, Indonesia

\section{PENDAHULUAN}

Perusahaan dalam menjalankan kegiatan operasional usaha tentu membutuhkan berbagai sumber daya, antara lain seperti modal, material, market dan mesin, Di samping aspek tersebut, perusahaan juga membutuhkan sumber daya manusia yang merupakan aspek penting dalam perusahaan, karena sumber daya manusia memiliki tanggung jawab, peran dan tugas di tiap jabatan yang berbeda beda. Sumber Daya Manusia yang dimaksud ialah karyawan. Perusahaan tentu 
menginginkan kinerja karyawan yang optimal sehingga sesuai dengan tujuan yang ditetapkan oleh perusahaan.

Berdasarkan teori yang dikemukakan oleh Becker (1993) pencapaian sasaran strategi perusahaan dapat diketahui dengan melakukan pengukuran kinerja secara menyeluruh terhadap indikator - indikator kinerja di tiap sasaran strategi yang ditetapkan. Keselarasan antara pengukuran kinerja dengan implementasi strategi merupakan salah satu cara yang bisa dilakukan untuk menghasilkan kinerja sumber daya manusia secara efektif dan efisien. Salah satu alat yang bisa digunakan oleh organisasi untuk mengukur kinerja sumber daya manusianya adalah dengan Human Resource Scorecard (HRSC).

Artikel ini meninjau berbagai penelitian terkait dengan Human Resource Scorecard yang masih terdapat beberapa research gap. Penelitian yang dilakukan oleh Queen (2019) yang meneliti perancangan sistem pengukuran kinerja SDM dengan Human Resource Scorecard dan proses pembobotan menggunakan Analytical Hierarchy Process (AHP) hanya menuliskan responden yang digunakan adalah karyawan PT. Krakatau Steel Divisi Slab Steel Plant 2 tanpa dijelaskan karyawan yang menjadi key informant untuk mengisi kuesioner penentuan Key Performance Indicator dan kuesioner pembobotan dengan Analytical Hierarchy Process. Hal serupa juga terjadi pada penelitian yang dilakukan oleh Rusindiyanto (2009) dimana dalam penelitian ini hanya menyebutkan responden yaitu karyawan PT. Arto Metal Internasional Sidoarjo tanpa menyebutkan secara detail karyawan yang menjadi key informant untuk mengisi kuesioner penentuan Key Performance Indicator serta kuesioner pembobotan dengan Analytical Hierarchy Process. Hasil penelitian yang dilakukan oleh Queen (2019) juga berhenti pada hasil pembobotan menggunakan Analytical Hierarchy Process dan tidak dilanjutkan menggunakan scoring system sehingga dapat diketahui secara lebih objektif dan detail kinerja organisasi yang diteliti.

Oleh karena itu, berdasarkan research gap dari beberapa penelitian terkait, peneliti ingin meneliti langkah - langkah Human Resource Scorecard untuk pengukuran kinerja karyawan pada kasus perusahaan di Indonesia. 


\section{TINJAUAN PUSTAKA}

\section{Human Resource Scorecard}

Human Resource Scorecard adalah suatu alat yang digunakan untuk mengukur kinerja sumber daya manusia sehingga sesuai dengan strategi yang diterapkan oleh perusahaan (Becker, 1993). Penggunaan konsep Human Resource Scorecard ini bertujuan untuk mengukur apakah investasi yang dilakukan pada bidang sumber daya manusia dalam perusahaan sudah tepat dengan sasaran yang ditetapkan perusahaan atau belum. Ada 4 (empat) perspektif dalam Human Resource Scorecard antara lain:

1. Perspektif finansial, yaitu perspektif yang memberikan guidelines dari strategi yang diterapkan dapat memberi kontribusi terhadap profitabilitas atau peningkatan laba perusahaan atau tidak. Ukuran utama terdiri atas laba operasional, economic value added, Return on Capital Employed (ROCE).

2. Perspektif pelanggan, yaitu perspektif yang dijadikan tolok ukur bahwa karyawan merupakan aset, user, atau output dari implementasi strategi SDM yang akan memiliki dampak terhadap customer. Ukuran utama dari perspektif ini terdiri dari tingkat kepuasan pelanggan, profitabilitas pelanggan, akuisisi customer baru.

3. Perspektif Proses Bisnis Internal, yaitu perspektif yang memberikan tolok ukur bahwa proses internal perusahaan akan memberikan dampak tercapainya tujuan secara finansial dan kepuasan pelanggan. Ukuran utama dari perspektif ini antara lain adalah bagaimana menyeimbangkan strategi bisnis dengan strategi SDM dalam perusahaan.

4. Perspektif Pembelajaran dan Pertumbuhan, yaitu perspektif yang berfokus pada strategi untuk pengembangan sumber daya manusia dalam perusahaan. Adapun ukuran dalam perspektif ini antara lain: tingkat kepuasan kerja karyawan, keterlibatan karyawan yang tinggi, dan output yang dihasilkan oleh karyawan.

\section{METODE}

Pada bagian Metode ini terdiri dari 3 (tiga) tahap, yaitu: Planning, Identifikasi Penelitian, dan Selection of Primary Studies. Tahap Planning adalah 
tahap dimana peneliti mendeskripsikan tujuan penelitian yang dilakukan. Tahap Identifikasi Penelitian adalah tahap dimana peneliti menjelaskan kriteria dan proses seleksi yang dilakukan. Tahap Selection of Primary Studies merupakan tahap dimana peneliti melakukan seleksi terhadap artikel penelitian dengan kata kunci yang digunakan serta kriteria seleksi yang sudah ditentukan pada tahap Identifikasi Penelitian sebelumnya.

\section{Planning}

Penelitian ini dilakukan untuk mengetahui implementasi HR Scorecard untuk pengukuran kinerja karyawan pada kasus perusahaan di Indonesia. Untuk dapat mengembangkan protokol review masalah yang spesifik maka dibutuhkan pertanyaan penelitian yang spesifik. Kriteria yang digunakan yaitu metode $H R$ Scorecard yang digunakan untuk mengukur kinerja karyawan. Berdasarkan hal tersebut, pertanyaan penelitiannya adalah "Bagaimana langkah-langkah penerapan HR Scorecard untuk pengukuran kinerja karyawan pada kasus perusahaan di Indonesia?

\section{Identifikasi Penelitian}

Untuk melakukan identifikasi penelitian, perlu menjelaskan terlebih dahulu kriteria untuk proses seleksi penelitian. Database yang digunakan dalam penelitian ini adalah berasal dari pencarian melalui Google Scholar. Kata kunci yang digunakan dalam pencarian adalah "HR Scorecard". Artikel penelitian yang telah ditemukan dari database tersebut kemudian dipilih berdasarkan kriteria yang ada pada tabel sebagai berikut.

Tabel 1. Kriteria Proses Seleksi

\begin{tabular}{|c|c|}
\hline Kriteria & Deskripsi \\
\hline Inclusion & $\begin{array}{l}\text { - Artikel penelitian sesuai dengan kata } \\
\text { kunci yaitu "HR Scorecard" } \\
\text { - Artikel penelitian yang menjawab } \\
\text { pertanyaan penelitian }\end{array}$ \\
\hline Exclusion & $\begin{array}{l}\text { - } \begin{array}{l}\text { Artikel penelitian yang tidak dalam } \\
\text { bentuk full text }\end{array} \\
\text { - Artikel penelitian yang menggunakan } \\
\text { HR Scorecard bukan untuk melakukan } \\
\text { pengukuran kinerja karyawan. } \\
\text { - Artikel penelitian dengan studi kasus } \\
\text { pada perusahaan yang tidak berada di } \\
\text { Indonesia }\end{array}$ \\
\hline
\end{tabular}




\section{Selection of Primary Studies}

Primary Studies ditemukan setelah mencari dari database dengan menggunakan kata kunci HR Scorecard dan hasilnya terdapat 98 artikel penelitian yang teridentifikasi. Pada tahap awal dalam proses seleksi, dilakukan dengan membaca judul serta abstrak penelitian, hasilnya diperoleh 53 artikel penelitian yang sesuai. Tahap kedua, dari 53 artikel yang diperoleh kemudian diseleksi menggunakan kriteria inklusi, hasilnya didapat 27 artikel yang sesuai. Tahap ketiga, dari 27 artikel yang didapatkan kemudian diseleksi menggunakan kriteria eksklusi dan didapatkan 10 artikel penelitian yang sesuai. Adapun jumlah artikel penelitian yang diseleksi dari tiap tahap digambarkan dalam tabel sebagai berikut.

Tabel 2. Selection of Primary Studies

\begin{tabular}{ccccc}
\hline Database & Discovery & $\mathbf{1}^{\text {st }}$ & $\mathbf{2}^{\text {nd }}$ & $\mathbf{3}^{\text {rd }}$ \\
\hline $\begin{array}{c}\text { Google } \\
\text { Scholar }\end{array}$ & 98 & 53 & 27 & 10 \\
\hline
\end{tabular}

Adapun 10 artikel yang diperoleh, secara keseluruhan merupakan jenis artikel jurnal penelitian. Berikut ini merupakan 10 artikel yang dipilih berdasarkan pada penelitian terdahulu sesuai dengan kriteria yang telah ditentukan. 
JEMAP: Jurnal Ekonomi, Manajemen, Akuntansi, dan Perpajakan

ISSN: 2622-612X (Media Online) | Vol.3 | No.2 | Oktober 2020

Tabel 3. Annotated Bibliography Penelitian Terkait

\begin{tabular}{|c|c|c|c|c|c|c|}
\hline No & $\begin{array}{c}\text { Penelitian } \\
\text { Terkait }\end{array}$ & Metode & $\begin{array}{l}\text { Faktor / Variabel } \\
\text { yang diteliti }\end{array}$ & $\begin{array}{l}\text { Sampel dan } \\
\text { Populasi }\end{array}$ & Hasil & Kritik / Masukan \\
\hline 1 & $\begin{array}{l}\text { (Maria Ulfa, } \\
2015) \quad \text { Analisis } \\
\text { Pengukuran } \\
\text { Kinerja } \\
\text { Karyawan } \\
\text { dengan Metode } \\
\text { Human Resource } \\
\text { Scorecard di } \\
\text { BMT Logam } \\
\text { Mulia }\end{array}$ & $\begin{array}{l}\text { Metode Human } \\
\text { Resource } \\
\text { Scorecard, } \\
\text { proses } \\
\text { pembobotan } \\
\text { dengan Metode } \\
\text { Analytical } \\
\text { Hierarchy } \\
\text { Process (AHP), } \\
\text { dan Scoring } \\
\text { System } \\
\text { menggunakan } \\
\text { teori } \\
\text { (Rusindiyanto, } \\
\text { 2009) }\end{array}$ & $\begin{array}{lr}\text { Human } & \text { Resource } \\
\text { Scorecard } & \text { dengan } \\
\text { berfokus } & \text { pada } 4 \\
\text { (empat) } & \text { perspektif } \\
\text { antara } & \text { lain: } \\
\text { Perspektif } & \text { finansial, } \\
\text { perspektif } & \\
\text { pelanggan, } & \\
\text { perspektif } & \text { operasi } \\
\text { dan } & \text { perspektif } \\
\text { strategi } & \end{array}$ & $\begin{array}{l}\text { Responden yang } \\
\text { digunakan } \\
\text { dalam penelitian } \\
\text { ini adalah } \\
\text { Manajer } \\
\text { Operasional "X" } \\
\text { KSPS BMT "X" } \\
\text { karena berperan } \\
\text { dalam } \\
\text { penentuan KPI } \\
\text { tiap perspektif } \\
\text { serta peran } \\
\text { dalam pengambilan } \\
\text { keputusan }\end{array}$ & $\begin{array}{l}\text { Hasil penelitian } \\
\text { diperoleh menunjukkan dari } \\
\text { perspektif finansial tahun } \\
2013 \text { menunjukkan skor } \\
\text { sebesar } 2,17 \text { yang berarti } \\
\text { kinerja karyawan dalam } \\
\text { kategori kurang, sedangkan } \\
\text { tahun 2014 sebesar } 3,17 \\
\text { termasuk kategori baik. } \\
\text { Perspektif pelanggan di } \\
\text { tahun } 2013 \text { memperoleh skor } \\
\text { sebesar } 3 \text { yang termasuk di } \\
\text { kategori sedang dan tahun } \\
2014 \text { sebesar } 3,79 \text { yang } \\
\text { termasuk kategori baik. } \\
\text { Perspektif operasi pada tahun } \\
\text { 2013 mendapat skor sebesar } \\
3,18 \text { yang termasuk kategori } \\
\text { sedang dan tahun 2014 } \\
\text { dengan skor sebesar } 3,88 \\
\text { yang termasuk dalam } \\
\text { kategori baik. Perspektif } \\
\text { strategi pada tahun 2013 } \\
\text { dengan skor sebesar } 3 \text { yang } \\
\text { termasuk kategori sedang }\end{array}$ & $\begin{array}{l}\text { Peneliti } \\
\text { memberikan } \\
\text { rekomendasi perbaikan } \\
\text { pengelolaan Sumber } \\
\text { Daya Manusia yang } \\
\text { dapat } \quad \text { diusulkan } \\
\text { berdasarkan } \quad \text { hasil } \\
\text { scoring system untuk } \\
\text { tiap perspektif Human } \\
\text { Resource Scorecard } \\
\text { yang diukur pada objek } \\
\text { penelitian }\end{array}$ \\
\hline
\end{tabular}


JEMAP: Jurnal Ekonomi, Manajemen, Akuntansi, dan Perpajakan

ISSN: 2622-612X (Media Online) | Vol.3 | No.2 | Oktober 2020

Tabel 3. Annotated Bibliography Penelitian Terkait

\begin{tabular}{|c|c|c|c|c|c|c|}
\hline No & $\begin{array}{c}\text { Penelitian } \\
\text { Terkait } \\
\end{array}$ & Metode & $\begin{array}{l}\text { Faktor / Variabel } \\
\text { yang diteliti }\end{array}$ & $\begin{array}{l}\text { Sampel dan } \\
\text { Populasi }\end{array}$ & Hasil & Kritik / Masukan \\
\hline & & & & & $\begin{array}{l}\text { dan tahun } 2014 \text { dengan skor } \\
\text { sebesar } 3,88 \text { yang termasuk } \\
\text { dalam kategori baik. Maka } \\
\text { secara keseluruhan dengan } \\
\text { melihat } 4 \text { perspektif } H R S C \text {, } \\
\text { tahun } 2013 \text { dengan skor } \\
\text { sebesar 3,01 yang termasuk } \\
\text { dalam kategori sedang dan } \\
\text { tahun } 2014 \text { sebesar } 3,85 \text { yang } \\
\text { termasuk dalam kategori } \\
\text { baik. }\end{array}$ & \\
\hline
\end{tabular}


JEMAP: Jurnal Ekonomi, Manajemen, Akuntansi, dan Perpajakan

ISSN: 2622-612X (Media Online) | Vol.3 | No.2 | Oktober 2020

Tabel 3. Annotated Bibliography Penelitian Terkait

\begin{tabular}{|c|c|c|c|c|c|c|}
\hline No & $\begin{array}{c}\begin{array}{c}\text { Penelitian } \\
\text { Terkait }\end{array} \\
\end{array}$ & Metode & $\begin{array}{c}\text { Faktor / Variabel } \\
\text { yang diteliti }\end{array}$ & $\begin{array}{c}\text { Sampel dan } \\
\text { Populasi } \\
\end{array}$ & Hasil & Kritik / Masukan \\
\hline 2 & $\begin{array}{l}\text { (Ermayanti, } \\
2015) \\
\text { Pengukuran } \\
\text { Kinerja SDM } \\
\text { Metode Human } \\
\text { Resources } \\
\text { Scorecard } \\
\text { Sebagai Upaya } \\
\text { Optimalisasi } \\
\text { Kinerja } \\
\text { Organisasi }\end{array}$ & $\begin{array}{l}\text { Metode Human } \\
\text { Resource } \\
\text { Scorecard, } \\
\text { proses } \\
\text { pembobotan } \\
\text { dengan Metode } \\
\text { Analytical } \\
\text { Hierarchy } \\
\text { Process (AHP) }\end{array}$ & $\begin{array}{lr}\text { Human } & \text { Resource } \\
\text { Scorecard } & \text { dengan } \\
\text { berfokus } & \text { pada } 4 \\
\text { (empat) } & \text { perspektif } \\
\text { yaitu: } & \text { financial, } \\
\text { customer, internal } \\
\text { business process dan } \\
\text { learning and growth }\end{array}$ & $\begin{array}{lr}\text { Penelitian ini } \\
\text { menggunakan } \\
\text { populasi seluruh } \\
\text { karyawan KSP } \\
\text { Sejahtera Jatim } \\
\text { sebanyak } \\
\text { orang, } \\
\text { sedangkan } \\
\text { sampel dalam } \\
\text { penelitian ini } \\
\text { terdiri dari } \\
\text { manajer, } \\
\text { accounting, } \\
\text { bagian } \\
\text { penjualan, kasir, } \\
\text { dan bagian } \\
\text { penagihan }\end{array}$ & 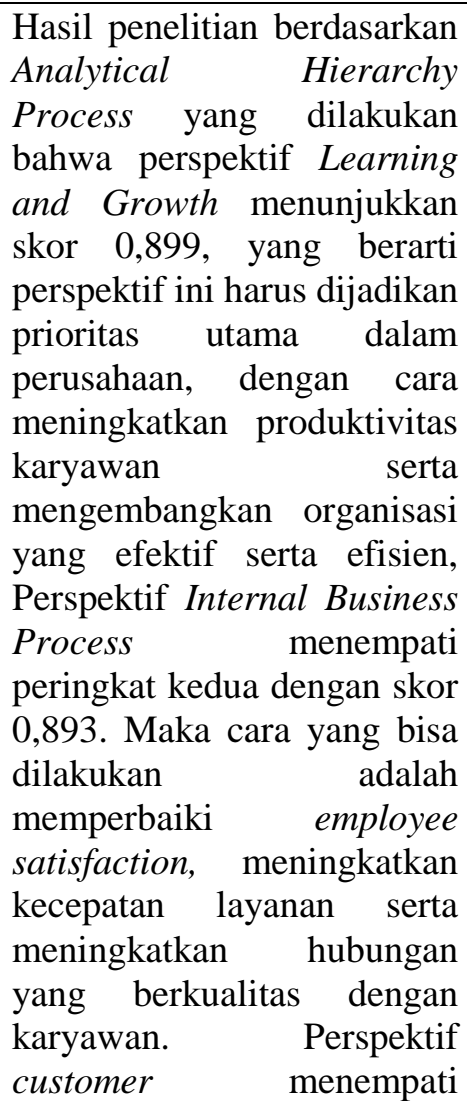 & $\begin{array}{l}\text { Hasil penelitian hanya } \\
\text { berhenti pada hasil } \\
\text { pembobotan Analytical } \\
\text { Hierarchy Process } \\
\text { (AHP) dan tidak } \\
\text { dilanjutkan pada } \\
\text { scoring system yang } \\
\text { akan menunjukkan } \\
\text { kinerja organisasi } \\
\text { secara lebih objektif } \\
\text { dari hasil scoring yang } \\
\text { didapatkan }\end{array}$ \\
\hline
\end{tabular}


JEMAP: Jurnal Ekonomi, Manajemen, Akuntansi, dan Perpajakan

ISSN: 2622-612X (Media Online) | Vol.3 | No.2 | Oktober 2020

Tabel 3. Annotated Bibliography Penelitian Terkait

\begin{tabular}{|c|c|c|c|c|c|c|}
\hline No & $\begin{array}{c}\text { Penelitian } \\
\text { Terkait }\end{array}$ & Metode & $\begin{array}{c}\text { Faktor / Variabel } \\
\text { yang diteliti } \\
\end{array}$ & $\begin{array}{c}\text { Sampel dan } \\
\text { Populasi }\end{array}$ & Hasil & Kritik / Masukan \\
\hline & & & & & $\begin{array}{l}\text { peringkat ketiga dengan skor } \\
0,883 \text {, maka cara yang bisa } \\
\text { dilakukan dengan } \\
\text { meningkatkan kepuasan } \\
\text { konsumen, customer service } \\
\text { dan prioritas konsumen. } \\
\text { Perspektif financial } \\
\text { menempati peringkat kelima } \\
\text { dengan skor 0,492, maka } \\
\text { cara yang bisa dilakukan } \\
\text { adalah memperbaiki dan } \\
\text { meningkatkan produktivitas } \\
\text { karyawan serta efisiensi di } \\
\text { bagian SDM. }\end{array}$ & \\
\hline
\end{tabular}


JEMAP: Jurnal Ekonomi, Manajemen, Akuntansi, dan Perpajakan

ISSN: 2622-612X (Media Online) | Vol.3 | No.2 | Oktober 2020

Tabel 3. Annotated Bibliography Penelitian Terkait

\begin{tabular}{|c|c|c|c|c|c|c|}
\hline No & $\begin{array}{c}\text { Penelitian } \\
\text { Terkait }\end{array}$ & Metode & $\begin{array}{c}\text { Faktor / Variabel } \\
\text { yang diteliti }\end{array}$ & $\begin{array}{l}\text { Sampel dan } \\
\text { Populasi }\end{array}$ & Hasil & Kritik / Masukan \\
\hline 3 & $\begin{array}{l}\text { (Rusindiyanto, } \\
\text { 2009) Analisis } \\
\text { Kinerja Sumber } \\
\text { Daya Manusia } \\
\text { Dengan Metode } \\
\text { Human Resource } \\
\text { Scorecard } \\
\text { (HRSC) Studi } \\
\text { Kasus di PT. Arto } \\
\text { Metal } \\
\text { Internasional } \\
\text { Sidoarjo }\end{array}$ & $\begin{array}{l}\text { Metode Human } \\
\text { Resource } \\
\text { Scorecard, } \\
\text { proses } \\
\text { pembobotan } \\
\text { dengan Metode } \\
\text { Analytical } \\
\text { Hierarchy } \\
\text { Process (AHP), } \\
\text { dan Scoring } \\
\text { System } \\
\text { menggunakan } \\
\text { teori } \\
\text { (Rusindiyanto, } \\
\text { 2009) }\end{array}$ & $\begin{array}{l}\text { Human Resource } \\
\text { Scorecard } \\
\text { berfokus pada } 4 \\
\text { (empat) perspektif } \\
\text { yaitu: Keuangan, } \\
\text { Pelanggan, Proses } \\
\text { Bisnis Internal, serta } \\
\text { Pembelajaran dan } \\
\text { Pertumbuhan }\end{array}$ & $\begin{array}{l}\text { Penelitian ini } \\
\text { menggunakan } \\
\text { responden yaitu } \\
\text { karyawan PT. } \\
\text { Arto Metal } \\
\text { Internasional } \\
\text { Sidoarjo }\end{array}$ & $\begin{array}{l}\text { Hasil dari penelitian ini } \\
\text { menunjukkan bahwa } \\
\text { perspektif keuangan di tahun } \\
2004 \text { menunjukkan skor } \\
\text { sebesar } 2,20 \text { yang termasuk } \\
\text { dalam kategori kurang dan } \\
\text { pada tahun } 2005 \\
\text { menunjukkan skor } 4,20 \text { yang } \\
\text { termasuk dalam kategori } \\
\text { baik. Perspektif pelanggan di } \\
\text { tahun } 2004 \text { menunjukkan } \\
\text { skor 2,57 yang termasuk } \\
\text { dalam kategori kurang dan } \\
\text { pada tahun } 2005 \\
\text { menunjukkan skor } 3,833 \\
\text { yang termasuk dalam } \\
\text { kategori sedang. Perspektif } \\
\text { proses bisnis internal di } \\
\text { tahun 2004 menunjukkan } \\
\text { skor 2,786 yang termasuk } \\
\text { dalam kategori sedang dan di } \\
\text { tahun 2005 menunjukkan } \\
\text { skor 3,23 yang juga termasuk } \\
\text { dalam kategori sedang. } \\
\text { Perspektif pembelajaran dan }\end{array}$ & $\begin{array}{l}\text { Peneliti hanya } \\
\text { menyebutkan } \\
\text { responden penelitian } \\
\text { yaitu karyawan PT. } \\
\text { Arto Metal } \\
\text { Internasional Sidoarjo } \\
\text { dan tidak menyebutkan } \\
\text { secara detail karyawan } \\
\text { yang menjadi key } \\
\text { informant untuk } \\
\text { mengisi kuesioner } \\
\text { pembobotan } \\
\text { menggunakan } \\
\text { Analytical Hierarchy } \\
\text { Process (AHP) dan } \\
\text { kuesioner penentuan } \\
\text { Key Performance } \\
\text { Indicator }\end{array}$ \\
\hline
\end{tabular}


JEMAP: Jurnal Ekonomi, Manajemen, Akuntansi, dan Perpajakan

ISSN: 2622-612X (Media Online) | Vol.3 | No.2 | Oktober 2020

Tabel 3. Annotated Bibliography Penelitian Terkait

\begin{tabular}{|c|c|c|c|c|c|c|}
\hline No & $\begin{array}{c}\text { Penelitian } \\
\text { Terkait }\end{array}$ & Metode & $\begin{array}{c}\text { Faktor / Variabel } \\
\text { yang diteliti }\end{array}$ & $\begin{array}{c}\text { Sampel dan } \\
\text { Populasi }\end{array}$ & Hasil & Kritik / Masukan \\
\hline & & & & & $\begin{array}{l}\text { pertumbuhan di tahun } 2004 \\
\text { menunjukkan skor } 1,333 \\
\text { yang termasuk dalam } \\
\text { kategori kurang dan di tahun } \\
2005 \text { menunjukkan skor } 2 \\
\text { yang juga termasuk dalam } \\
\text { kategori kurang. }\end{array}$ & \\
\hline 4 & $\begin{array}{l}\text { (Queen, 2019) } \\
\text { Perancangan } \\
\text { Sistem } \\
\text { Pengukuran } \\
\text { Kinerja Sumber } \\
\text { Daya Manusia } \\
\text { dengan } \\
\text { Pendekatan } \\
\text { Human Resource } \\
\text { Scorecard }\end{array}$ & $\begin{array}{l}\text { Metode Human } \\
\text { Resource } \\
\text { Scorecard, } \\
\text { proses } \\
\text { pembobotan } \\
\text { dengan Metode } \\
\text { Analytical } \\
\text { Hierarchy } \\
\text { Process (AHP) }\end{array}$ & $\begin{array}{lr}\text { Human } & \text { Resource } \\
\text { Scorecard } & \text { yang } \\
\text { berfokus } & \text { pada } \\
\text { Perspektif } & \text { Filosofi } \\
\text { SDM, Kebijakan } \\
\text { SDM, r Program } \\
\text { SDM, Praktik SDM, } \\
\text { dan Proses SDM }\end{array}$ & $\begin{array}{lr}\text { Penelitian } & \text { ini } \\
\text { menggunakan } & \\
\text { responden dari } & \text { de } \\
\text { perusahaan } & \text { PT. } \\
\text { Krakatau Steel } \\
\text { Divisi Slab } & \text { Steel } \\
\text { Plant } & 2 \\
\text { sebanyak } & 35 \\
\text { orang } & \end{array}$ & $\begin{array}{l}\text { Penilaian kinerja yang } \\
\text { diperoleh berdasarkan hasil } \\
\text { penelitian pada bagian SDM } \\
\text { divisi slab steel plant } 2 \text { pada } \\
\text { masing - masing perspektif } \\
\text { sebagai berikut: Filosofi } \\
\text { SDM dengan skor } 3,25 \text {, } \\
\text { Kebijakan SDM dengan skor } \\
3,297 \text {, Program SDM dengan } \\
\text { skor 5, Praktik SDM dengan } \\
\text { skor 4,75 maka secara } \\
\text { komprehensif skor yang } \\
\text { didapat pada divisi slab steel } \\
\text { plant } 2 \text { adalah } 3,845 \text { yang } \\
\text { mengindikasikan kinerja dari } \\
\text { divisi ini sudah berada dalam } \\
\text { kategori cukup baik. }\end{array}$ & $\begin{array}{l}\text { Hasil penelitian } \\
\text { berhenti pada hasil } \\
\text { pembobotan } \\
\text { menggunakan } \\
\text { Analytical Hierarchy } \\
\text { Process (AHP) dan } \\
\text { tidak dilanjutkan } \\
\text { menggunakan scoring } \\
\text { system sehingga dapat } \\
\text { diketahui secara lebih } \\
\text { objektif dan detail } \\
\text { kinerja organisasi yang } \\
\text { diteliti }\end{array}$ \\
\hline
\end{tabular}


JEMAP: Jurnal Ekonomi, Manajemen, Akuntansi, dan Perpajakan

ISSN: 2622-612X (Media Online) | Vol.3 | No.2 | Oktober 2020

Tabel 3. Annotated Bibliography Penelitian Terkait

\begin{tabular}{|c|c|c|c|c|c|c|}
\hline No & $\begin{array}{c}\text { Penelitian } \\
\text { Terkait }\end{array}$ & Metode & $\begin{array}{c}\text { Faktor / Variabel } \\
\text { yang diteliti }\end{array}$ & $\begin{array}{c}\text { Sampel dan } \\
\text { Populasi }\end{array}$ & Hasil & Kritik / Masukan \\
\hline 5 & $\begin{array}{l}\text { Mardatillah, } \\
2013 \text { ) Evaluasi } \\
\text { Kinerja } \\
\text { Manajemen } \\
\text { Sumber Daya } \\
\text { Manusia } \\
\text { Bank PT. } \\
\text { Dengan Human } \\
\text { Resource } \\
\text { Scorecard }\end{array}$ & $\begin{array}{l}\text { Metode Human } \\
\text { Resource } \\
\text { Scorecard, } \\
\text { dengan } \\
\text { menggunakan } \\
\text { indikator leading } \\
\text { dan lagging }\end{array}$ & $\begin{array}{lr}\text { Human } & \text { Resource } \\
\text { Scorecard } & \text { yang } \\
\text { berfokus } & \text { pada } \\
\text { perspektif } & \text { bisnis } \\
\text { perbankan } & \text { antara } \\
\text { lain BOPO } & \text { (Biaya } \\
\text { Operasional terhadap } \\
\text { Pendapatan } \\
\text { Operasional), LDR } \\
\text { (Load Deposit } \\
\text { Ratio), NIM (Net } \\
\text { Interest Margin) }\end{array}$ & $\begin{array}{l}\text { Penelitian ini } \\
\text { menggunakan } \\
\text { responden } \\
\text { sebanyak } 23 \\
\text { orang } 4 \text { orang di } \\
\text { level pimpinan, } \\
\text { dan } 19 \text { orang di } \\
\text { level pelaksana } \\
\text { terampil }\end{array}$ & $\begin{array}{l}\text { Hasil penelitian yang didapat } \\
\text { dari penilaian kinerja yang } \\
\text { dilakukan terhadap } 18 \text { orang } \\
\text { karyawan yang menempati } \\
23 \text { jabatan yang ada di } \\
\text { perusahaan dapat diketahui } \\
\text { bahwa } 16,67 \% \text { kinerja } \\
\text { karyawan termasuk dalam } \\
\text { kategori sangat baik, } 44,44 \% \\
\text { kinerja karyawan termasuk } \\
\text { dalam kategori baik, dan } \\
38,89 \% \text { kinerja karyawan } \\
\text { termasuk di kategori rata - } \\
\text { rata. }\end{array}$ & $\begin{array}{l}\text { Dalam } \\
\text { pengidentifikasian } \\
\text { Tolok } \\
\text { Pengukuran } \\
\text { SDM perlu } \\
\text { identifikasi } \\
\text { literatur - literatur yang } \\
\text { didapat dari jurnal } \\
\text { terkait maupun buku, } \\
\text { tidak hanya meminta } \\
\text { pendapat pengelola } \\
\text { SDM dalam organisasi } \\
\text { saja sehingga } \\
\text { mendapatkan tolok } \\
\text { ukur yang dinilai lebih } \\
\text { valid. }\end{array}$ \\
\hline
\end{tabular}


JEMAP: Jurnal Ekonomi, Manajemen, Akuntansi, dan Perpajakan

ISSN: 2622-612X (Media Online) | Vol.3 | No.2 | Oktober 2020

Tabel 3. Annotated Bibliography Penelitian Terkait

\begin{tabular}{|c|c|c|c|c|c|c|}
\hline No & $\begin{array}{c}\text { Penelitian } \\
\text { Terkait }\end{array}$ & Metode & $\begin{array}{c}\text { Faktor / Variabel } \\
\text { yang diteliti }\end{array}$ & $\begin{array}{c}\text { Sampel dan } \\
\text { Populasi }\end{array}$ & Hasil & Kritik / Masukan \\
\hline 6 & $\begin{array}{l}\text { (Sahaya \& } \\
\text { Wahyuni, 2017) } \\
\text { Pengukuran } \\
\text { Kinerja } \\
\text { Karyawan } \\
\text { dengan Metode } \\
\text { Human Resource } \\
\text { Scorecard dan } \\
\text { AHP (Studi } \\
\text { Kasus: PT. Bella } \\
\text { Citra Mandiri } \\
\text { Sidoarjo }\end{array}$ & $\begin{array}{l}\text { Metode Human } \\
\text { Resource } \\
\text { Scorecard } \\
\text { proses } \\
\text { pembobotan } \\
\text { dengan Metode } \\
\text { Anlytical } \\
\text { Hierarchy } \\
\text { Process (AHP), } \\
\text { dan Scoring } \\
\text { System } \\
\text { menggunakan } \\
\text { teori } \\
\text { (Rusindiyanto, } \\
\text { 2009) }\end{array}$ & 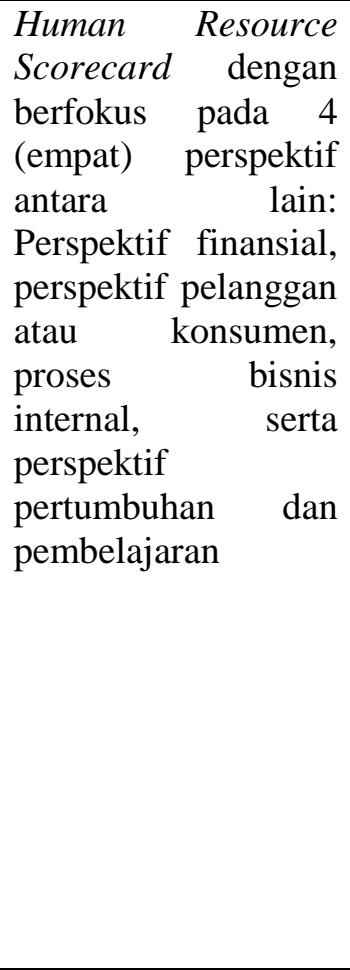 & $\begin{array}{l}\text { Supervisor dari } \\
\text { PT Bella Citra } \\
\text { Mandiri } \\
\text { Sidoarjo selaku } \\
\text { orang yang } \\
\text { berkompeten } \\
\text { dan mempunyai } \\
\text { peran penting } \\
\text { dalam } \\
\text { pengambilan } \\
\text { keputusan serta } \\
\text { dalam } \\
\text { menentukan KPI } \\
\text { masing-masing } \\
\text { perspektif }\end{array}$ & 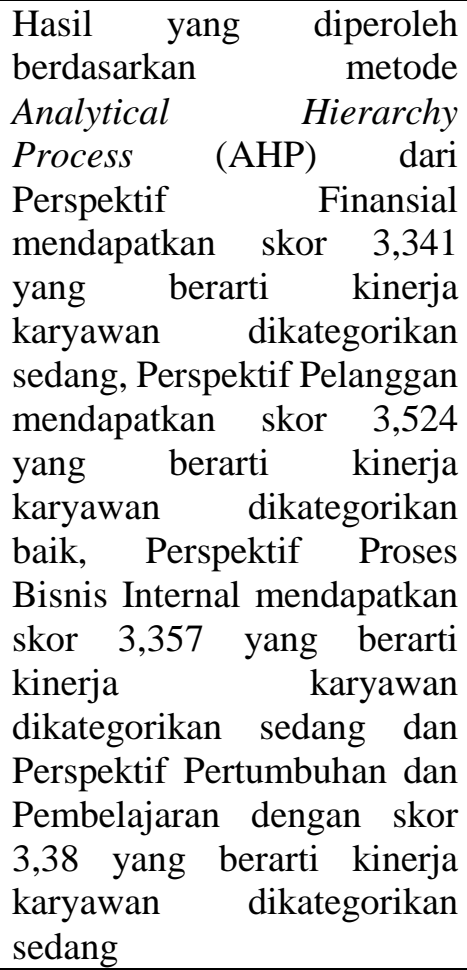 & 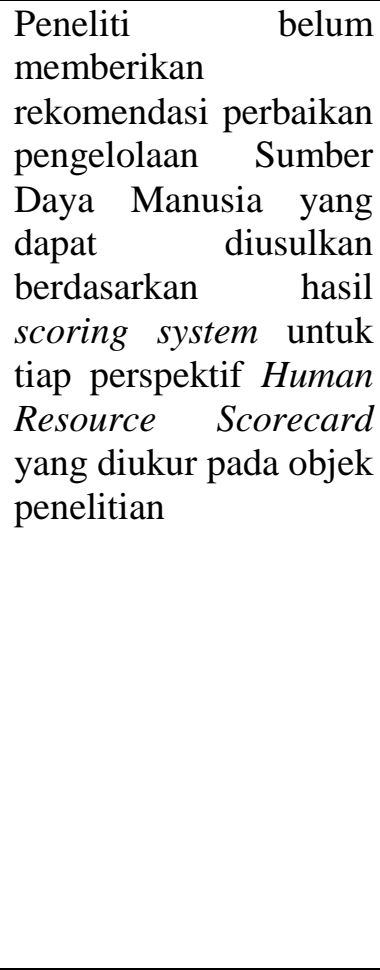 \\
\hline
\end{tabular}


JEMAP: Jurnal Ekonomi, Manajemen, Akuntansi, dan Perpajakan

ISSN: 2622-612X (Media Online) | Vol.3 | No.2 | Oktober 2020

Tabel 3. Annotated Bibliography Penelitian Terkait

\begin{tabular}{|c|c|c|c|c|c|c|}
\hline No & $\begin{array}{c}\text { Penelitian } \\
\text { Terkait }\end{array}$ & Metode & $\begin{array}{c}\text { Faktor / Variabel } \\
\text { yang diteliti }\end{array}$ & $\begin{array}{c}\text { Sampel dan } \\
\text { Populasi }\end{array}$ & Hasil & Kritik / Masukan \\
\hline 7 & $\begin{array}{l}\text { (Astuti et al., } \\
2015) \\
\text { Perancangan Alat } \\
\text { Ukur Kinerja } \\
\text { Sumber Daya } \\
\text { Manusia di Unit } \\
\text { Donor Darah } \\
\text { (UDD) PMI Kota } \\
\text { Bandung Dengan } \\
\text { Menggunakan } \\
\text { Metode Human } \\
\text { Resource } \\
\text { Scorecard }\end{array}$ & $\begin{array}{l}\text { Metode Human } \\
\text { Resource } \\
\text { Scorecard, } \\
\text { proses } \\
\text { pembobotan } \\
\text { dengan Metode } \\
\text { Analytical } \\
\text { Hierarchy } \\
\text { Process (AHP) } \\
\text { dan Scoring } \\
\text { System } \\
\text { menggunakan } \\
\text { metode Higher is } \\
\text { better, Lower is } \\
\text { Better, Must be } \\
\text { Zero dan Must Be } \\
\text { One }\end{array}$ & 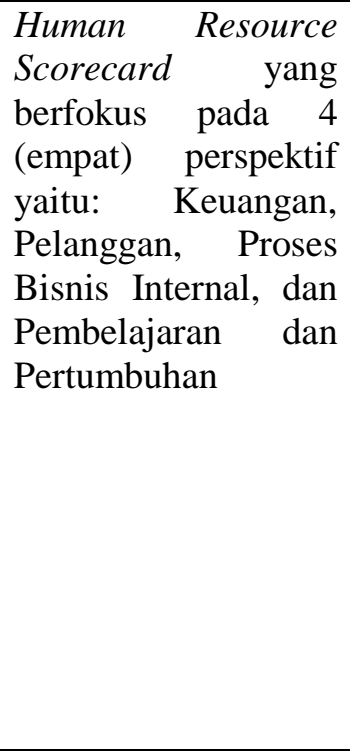 & $\begin{array}{l}\text { Penelitian ini } \\
\text { menggunakan } \\
\text { responden yaitu } \\
\text { Bagian } \\
\text { Kepegawaian } \\
\text { UDD PMI Kota } \\
\text { Bandung } \\
\text { sebagai key } \\
\text { informant }\end{array}$ & $\begin{array}{l}\text { Hasil penelitian } \\
\text { menunjukkan, dari perspektif } \\
\text { keuangan mendapatkan hasil } \\
104,53 \text { yang termasuk dalam } \\
\text { kategori baik, perspektif } \\
\text { proses bisnis internal } \\
\text { mendapatkan hasil } 91,30 \\
\text { yang termasuk dalam } \\
\text { kategori baik, perspektif } \\
\text { pelanggan mendapatkan } \\
\text { hasil 101,16 yang termasuk } \\
\text { dalam kategori baik, dan } \\
\text { perspektif pembelajaran dan } \\
\text { pertumbuhan mendapatkan } \\
\text { hasil } 89,44 \text { yang termasuk } \\
\text { dalam kategori baik }\end{array}$ & $\begin{array}{l}\text { Peneliti belum } \\
\text { menjelaskan detail key } \\
\text { informant yang } \\
\text { bertanggungjawab } \\
\text { untuk mengisi } \\
\text { kuesioner pembobotan } \\
\text { menggunakan } \\
\text { Analytical Hierarchy } \\
\text { Process (AHP) dan } \\
\text { kuesioner penentuan } \\
\text { Key Performance } \\
\text { Indicator (KPI) }\end{array}$ \\
\hline
\end{tabular}


JEMAP: Jurnal Ekonomi, Manajemen, Akuntansi, dan Perpajakan

ISSN: 2622-612X (Media Online) | Vol.3 | No.2 | Oktober 2020

Tabel 3. Annotated Bibliography Penelitian Terkait

\begin{tabular}{|c|c|c|c|c|c|c|}
\hline No & $\begin{array}{c}\text { Penelitian } \\
\text { Terkait } \\
\end{array}$ & Metode & $\begin{array}{c}\text { Faktor / Variabel } \\
\text { yang diteliti }\end{array}$ & $\begin{array}{c}\text { Sampel dan } \\
\text { Populasi }\end{array}$ & Hasil & kan \\
\hline 8 & $\begin{array}{l}\text { (Ramadhan et al., } \\
\text { 2017) } \\
\text { Perancangan dan } \\
\text { Pengukuran } \\
\text { Kinerja Sumber } \\
\text { Daya Manusia } \\
\text { dengan Metode } \\
\text { Human Resource } \\
\text { Scorecard } \\
\text { (HRSC) (Studi } \\
\text { Kasus PG. Krebet } \\
\text { Baru } \\
\text { Bululawang) }\end{array}$ & $\begin{array}{l}\text { Metode Human } \\
\text { Resource } \\
\text { Scorecard, } \\
\text { proses } \\
\text { pembobotan } \\
\text { menggunakan } \\
\text { Metode AHP } \\
\text { (Analytical } \\
\text { Hierarchy dan } \\
\text { Process), System } \\
\text { Scoring Metode } \\
\text { dengan } \\
\text { OMAX } \\
\text { (Objective } \\
\text { Matrix) }\end{array}$ & $\begin{array}{lr}\text { Human } & \text { Resource } \\
\text { Scorecard } & \text { dengan } \\
\text { berfokus } & \text { pada } 4 \\
\text { Perspektif } & \text { antara } \\
\text { lain: } & \text { Perspektif } \\
\text { Keuangan,Perspektif } \\
\text { Pelanggan,Perspektif } \\
\text { Proses } & \text { Bisnis } \\
\text { Internal; } & \text { Perspektif } \\
\text { Pembelajaran } & \& \\
\text { Pertumbuhan } & \text { yang } \\
\text { tiap perspektifnya } \\
\text { terdapat } & \text { strategy } \\
\text { objective, } & \text { program } \\
\text { inisiatif } & \text { serta } \\
\text { aktivitas } & \text { yang } \\
\text { dijalankan } & \end{array}$ & $\begin{array}{lr}\text { Empat } & \text { kepala } \\
\text { seksi } & \text { dalam } \\
\text { Divisi SDM dan } & \text { dM } \quad \text { PG } \\
\text { UMUM } & \text { Krebet } \quad \text { Baru } \\
\text { Bululawang } \\
\text { yaitu } & \text { Kepala } \\
\text { Seksi } & \text { SDM, } \\
\text { Kepala } & \text { Seksi } \\
\text { Umum, Kepala } \\
\text { Seksi Kendaraan } \\
\text { dan Kepala } \\
\text { Seksi Rupa - } \\
\text { Rupa }\end{array}$ & $\begin{array}{l}\text { Kinerja dari Divisi SDM dan } \\
\text { Umum secara komprehensif } \\
\text { sudah mencapai performa } \\
\text { yang diharapkan karena } \\
\text { berada pada kategori hijau, } \\
\text { yang menunjukkan secara } \\
\text { keseluruhan kinerja sudah } \\
\text { mencapai target yang telah } \\
\text { ditetapkan. Sedangkan hasil } \\
\text { pengukuran kinerja dari } \\
\text { program inisiatif didapatkan } \\
\text { hasil dimana terdapat } 8 \\
\text { (delapan) program inisiatif } \\
\text { yang termasuk dalam } \\
\text { kategori hijau, 5 (lima) } \\
\text { program inisiatif yang } \\
\text { termasuk dalam kategori } \\
\text { kuning dan sebanyak } 1 \text { (satu) } \\
\text { program inisiatif yang } \\
\text { termasuk dalam kategori } \\
\text { merah }\end{array}$ & $\begin{array}{lr}\text { Perlu dijelaskan lebih } \\
\text { detail terkait Scoring } \\
\text { System menggunakan } \\
\text { metode } & \text { Traffic Light } \\
\text { System, khususnya } & \text { dengan } \\
\text { terkait } & \text { level } \\
\text { penentuan } & \text { Strategy } \\
\text { perspektif, } & \text { Program } \\
\text { Objective, } & \text { Progisiatif, dan Aktivitas. } \\
\text { Inisia } & \text { Sehingga pembaca bisa } \\
\text { lebih } & \text { memahami } \\
\text { dengan jelas langkah } \\
\text { yang ada pada metode } \\
\text { Scoring System yang } \\
\text { digunakan }\end{array}$ \\
\hline 9 & $\begin{array}{l}\text { (Prasetya, 2016) } \\
\text { Pengukuran } \\
\text { Kinerja Pegawai } \\
\text { Dengan }\end{array}$ & $\begin{array}{l}\text { Metode Human } \\
\text { Resource } \\
\text { Scorecard, } \\
\text { dengan scoring }\end{array}$ & $\begin{array}{lr}\text { Human } & \text { Resource } \\
\text { Scorecard } & \text { yang } \\
\text { berfokus } & \text { pada } \\
\text { Perspektif } & \text { Financial, }\end{array}$ & $\begin{array}{l}\text { Penelitian ini } \\
\text { menggunakan } \\
\text { responden yaitu } \\
\text { seluruh }\end{array}$ & $\begin{array}{l}\text { Hasil } \\
\text { menunjukkan skon ditian } \\
\text { Perspektif finansial sebesar } \\
\text { 30\%, Perspektif Pelanggan }\end{array}$ & $\begin{array}{lr}\text { Perlu } & \text { dijelaskan } \\
\text { responden } & \text { yang } \\
\text { bertanggung } & \text { jawab } \\
\text { untuk } & \text { mengisi } \\
\end{array}$ \\
\hline
\end{tabular}


JEMAP: Jurnal Ekonomi, Manajemen, Akuntansi, dan Perpajakan

ISSN: 2622-612X (Media Online) | Vol.3 | No.2 | Oktober 2020

Tabel 3. Annotated Bibliography Penelitian Terkait

\begin{tabular}{|c|c|c|c|c|c|c|}
\hline No & $\begin{array}{c}\text { Penelitian } \\
\text { Terkait }\end{array}$ & Metode & $\begin{array}{l}\text { Faktor / Variabel } \\
\text { yang diteliti }\end{array}$ & $\begin{array}{l}\text { Sampel dan } \\
\text { Populasi }\end{array}$ & Hasil & Kritik / Masukan \\
\hline & $\begin{array}{l}\text { Menggunakan } \\
\text { Human Resource } \\
\text { Scorecard Studi } \\
\text { padar Kantor } \\
\text { Pelayaan } \\
\text { Kekayaan Negara } \\
\text { dan } \quad \text { Lelang } \\
\text { Manado }\end{array}$ & $\begin{array}{l}\text { system } \\
\text { menggunakan } \\
\text { metode Traffic } \\
\text { Light System }\end{array}$ & $\begin{array}{l}\text { Perspektif } \\
\text { Pelanggan, } \\
\text { Perspektif Proses } \\
\text { Bisnis Internal, dan } \\
\text { Perspektif } \\
\text { Pertumbuhan dan } \\
\text { Pembelajaran }\end{array}$ & $\begin{array}{l}\text { karyawan } \\
\text { Kantor } \\
\text { Pelayanan } \\
\text { Kekayaan } \\
\text { Negara dan } \\
\text { Lelang Manado }\end{array}$ & $\begin{array}{l}\text { sebesar } 16,85 \%, \text { Perspektif } \\
\text { Proses } \quad \text { Bisnis } \text { Internal } \\
\text { sebesar } 33,23 \%, \quad \text { dan } \\
\text { Perspektif Pembelajaran dan } \\
\text { Pertumbuhan } \\
33,31 \% \text { sebesar } \\
\text { komprehensif } \\
\text { keempat perspektif tersebut } \\
\text { dilihat dari traffic light } \\
\text { system termasuk dalam } \\
\text { kategori hijau dengan skor } \\
113,39 \%, \text { yang berarti secara } \\
\text { keseluruhan berkinerja baik. }\end{array}$ & $\begin{array}{lr}\text { kuesioner } & \text { pembobotan } \\
\text { perspektif } & \text { dan } \\
\text { kuesioner } & \text { penentuan } \\
\text { key } & \text { performance } \\
\text { indicator } & \end{array}$ \\
\hline
\end{tabular}


JEMAP: Jurnal Ekonomi, Manajemen, Akuntansi, dan Perpajakan

ISSN: 2622-612X (Media Online) | Vol.3 | No.2 | Oktober 2020

Tabel 3. Annotated Bibliography Penelitian Terkait

\begin{tabular}{|c|c|c|c|c|c|c|}
\hline No & $\begin{array}{c}\text { Penelitian } \\
\text { Terkait }\end{array}$ & Metode & $\begin{array}{c}\text { Faktor / Variabel } \\
\text { yang diteliti }\end{array}$ & $\begin{array}{c}\text { Sampel dan } \\
\text { Populasi }\end{array}$ & Hasil & Kritik / Masukan \\
\hline 10 & $\begin{array}{l}\text { (Putri \& } \\
\text { Handayani, 2015) } \\
\text { Pengukuran } \\
\text { Kinerja } \\
\text { Karyawan PT. } \\
\text { Pertamina } \\
\text { Persero TBBM } \\
\text { Semarang Group } \\
\text { dengan } \\
\text { Pendekatan } \\
\text { Human Resource } \\
\text { Scorecard }\end{array}$ & $\begin{array}{l}\text { Metode Human } \\
\text { Resource } \\
\text { Scorecard, } \\
\text { proses } \\
\text { pembobotan } \\
\text { dengan Metode } \\
\text { Analytical } \\
\text { Hierarchy } \\
\text { Process (AHP) } \\
\text { dan Scoring } \\
\text { System } \\
\text { menggunakan } \\
\text { metode Higher is } \\
\text { better, Lower is } \\
\text { Better, Must be } \\
\text { Zero dan Must Be } \\
\text { One }\end{array}$ & $\begin{array}{l}\text { Human Resource } \\
\text { Scorecard dengan } \\
\text { Perspektif yang } \\
\text { mengacu pada Key } \\
\text { Performance } \\
\text { Indicator yang } \\
\text { ditetapkan } \\
\text { perusahaan antara } \\
\text { lain HR Efficiency, } \\
\text { High Performance } \\
\text { Work System, HR } \\
\text { System Alignment, } \\
\text { dan HR Deliverable }\end{array}$ & $\begin{array}{l}\text { Empat } \\
\text { responden yang } \\
\text { berkompeten di } \\
\text { PT Pertamina } \\
\text { Persero TBBM } \\
\text { Semarang } \\
\text { Group antara } \\
\text { lain: Senior } \\
\text { Supervisor PPP, } \\
\text { Supervisor HSE, } \\
\text { dan Adm. TMC. }\end{array}$ & $\begin{array}{l}\text { Hasil Pengukuran Kinerja } \\
\text { yang sudah dilakukan pada } \\
20 \quad \text { Key Performance } \\
\text { Indicator yang sudah } \\
\text { dilakukan validasi oleh } \\
\text { perusahaan, didapat hasil } 12 \\
\text { Key Performance Indicator } \\
\text { berada dalam kategori hijau, } \\
6 \text { Key Performance Indicator } \\
\text { berada dalam kategori } \\
\text { kuning, dan } 2 \text { Key } \\
\text { Performance Indicator } \\
\text { berada dalam kategori merah } \\
\text { yang terkait dengan tingkat } \\
\text { keterlambatan karyawan dan } \\
\text { biaya penjagaan lingkungan }\end{array}$ & $\begin{array}{l}\text { Rekomendasi } \\
\text { sebaiknya juga } \\
\text { diberikan pada hasil } \\
\text { scoring system yang } \\
\text { masuk pada kategori } \\
\text { hijau (green) dan } \\
\text { kuning (yellow), agar } \\
\text { perusahaan memiliki } \\
\text { guidelines untuk } \\
\text { mempertahankan } \\
\text { kinerja yang sudah baik } \\
\text { saat pengukuran } \\
\text { kinerja ini dilakukan. }\end{array}$ \\
\hline
\end{tabular}


JEMAP: Jurnal Ekonomi, Manajemen, Akuntansi, dan Perpajakan

ISSN: 2622-612X (Media Online) | Vol.3 | No.2 | Oktober 2020

\section{HASIL}

Berdasarkan pertanyaan penelitian yang diajukan diatas yaitu terkait implementasi HR Scorecard untuk pengukuran kinerja karyawan, dan berdasarkan pada hasil literature review yang sudah dilakukan menemukan beberapa kesamaan terkait implementasi HR Scorecard.

1. Tahap awal implementasi $H R$ Scorecard dilakukan dengan penentuan proses bisnis dari masing - masing perspektif. Berdasarkan artikel penelitian yang sudah penulis review, 7 (tujuh) dari 10 (sepuluh) artikel penelitian menyebutkan perspektif pengukuran yang sama yaitu: Perspektif Pelanggan, Perspektif Keuangan, Perspektif Proses Bisnis Internal, serta Perspektif Pembelajaran \& Pertumbuhan. Sedangkan 3 (tiga) artikel penelitian lain menyebut perspektif pengukuran berbeda yang didasarkan pada kondisi bisnis obyek penelitian dilakukan.

a. Penelitian yang dilakukan oleh Mardatillah (2013) menyebutkan perspektif bisnis perbankan antara lain BOPO (Biaya Operasional Terhadap Pendapatan Operasional), LDR (Load Deposit Ratio), NIM (Net Interest Margin).

b. Penelitian yang dilakukan oleh Putri \& Handayani (2015) menyebutkan perspektif dari perusahaan yang diteliti yaitu HR Efficiency, High Performance Work System, HR System Alignment, dan HR Deliverable.

2. Menentukan Key Performance Indicator dari proses bisnis masing - masing perspektif yang sudah ditentukan. (Sahaya \& Wahyuni, 2017)

3. Melakukan perhitungan bobot masing - masing perspektif menggunakan metode Analytical Hierarchy Process (AHP), dimana tahapan yang digunakan sebagai berikut.

a. Tahap awal perhitungan bobot menggunakan Analytical Hierarchy Process berdasarkan penelitian yang dilakukan oleh Astuti et al. (2015) adalah Membuat hirarki permasalahan yang digunakan untuk mengidentifikasi permasalahan yang kompleks ke dalam sub sistem atau elemen yang menghasilkan gambaran lebih jelas dan detail. 
b. Menentukan prioritas

Berdasarkan penelitian yang dilakukan oleh Putri \& Handayani (2015), Penentuan prioritas elemen dilakukan dengan:

a) Menyusun matriks perbandingan berpasangan, yaitu membandingkan elemen - elemen secara berpasangan sesuai dengan kriteria yang diberikan

b) Matriks perbandingan berpasangan diisi menggunakan bilangan/angka yang menjadi representasi kepentingan relatif antara satu elemen dengan elemen lain.

c. Melakukan sintesis

Sintesis ini dilakukan berdasarkan pertimbangan - pertimbangan terhadap perbandingan berpasangan sehingga diperoleh hasil keseluruhan dari prioritas. Berdasarkan penelitian yang dilakukan oleh Ramadhan et al. (2017), langkah yang digunakan antara lain:

a) Menjumlahkan nilai dari setiap kolom pada matriks perbandingan berpasangan.

b) Membagi masing - masing nilai dari kolom dengan total kolom untuk memperoleh hasil normalisasi matriks.

c) Menjumlah nilai dari masing - masing baris lalu membaginya dengan jumlah elemen untuk didapatkan nilai rata - rata.

d. Mengukur Konsistensi

Konsistensi yang diperoleh berdasarkan hasil perhitungan harus mendapatkan nilai yang baik, karena keputusan yang baik dapat dihasilkan dari nilai konsistensi yang baik. Berdasarkan penelitian oleh Putri \& Handayani (2015), langkah yang dilakukan dalam mengukur konsistensi sebagai berikut.

a) Melakukan pengalian nilai pada kolom pertama dengan prioritas relatif elemen. pertama, nilai kolom kedua dengan prioritas relatif elemen kedua, dan seterusnya

b) Melakukan penjumlahan setiap baris. 
c) Hasil dari penjumlahan pada baris dibagi dengan elemen prioritas relatif yang bersangkutan.

d) Hasil pembagian tersebut dijumlahkan dengan banyaknya elemen yang ada, dan hasil tersebut disebut sebagai $\lambda$ maks.

e. Dilakukan perhitungan rasio konsistensi, berdasarkan penelitian Rusindiyanto (2009), rumus yang digunakan untuk menghitung rasio konsistensi sebagai berikut.

$$
\begin{aligned}
\mathrm{CR}=\mathrm{CI} / \mathrm{IR}, \text { dimana: } \mathrm{CR} & =\text { Consistency } \text { Ratio } \\
\mathrm{CI} & =\text { Consistency Index } \\
\mathrm{IR} & =\text { Indeks Random Consistency }
\end{aligned}
$$

f. Memeriksa konsistensi dari hirarki, apabila nilai lebih dari $10 \%$ maka penilaian data perlu diperbaiki, namun apabila rasio konsistensi kurang atau sama dengan 10\%, maka hasil perhitungan tersebut dinyatakan benar. (Rusindiyanto, 2009)

4. Melakukan perhitungan Scoring System

Berdasarkan penelitian Ramadhan et al. (2017), tahap selanjutnya adalah melakukan perhitungan Scoring System. Perhitungan tersebut dilakukan untuk mengetahui nilai pencapaian terhadap target masing - masing key performance indicator (KPI), sehingga dengan mengetahui nilai pencapaian tersebut dapat dilakukan identifikasi perlunya suatu perbaikan kinerja.

5. Memberikan rekomendasi perbaikan kinerja karyawan berdasarkan hasil Scoring System

Berdasarkan penelitian yang dilakukan (Ramadhan et al., 2017), tahap terakhir dari langkah penerapan Human Resource Scorecard adalah memberikan rekomendasi untuk perbaikan kinerja. Rekomendasi perbaikan kinerja diberikan kepada perusahaan atas pengukuran kinerja yang teridentifikasi pada hasil scoring system yang diperoleh, sehingga perusahaan bisa mengetahui perspektif yang diperlukan sehingga dilakukan langkah perbaikan untuk menghasilkan kinerja karyawan yang lebih optimal. 
JEMAP: Jurnal Ekonomi, Manajemen, Akuntansi, dan Perpajakan

ISSN: 2622-612X (Media Online) | Vol.3 | No.2 | Oktober 2020

\section{KESIMPULAN DAN SARAN \\ KESIMPULAN}

Berdasarkan hasil literature review yang sudah peneliti lakukan, serta meninjau pertanyaan penelitian yang diajukan pada penelitian ini, peneliti mendapatkan hasil terkait langkah - langkah penerapan Human Resource Scorecard untuk mengukur kinerja sumber daya manusia pada kasus perusahaan di Indonesia, antara lain: penentuan proses bisnis dari masing - masing perspektif, menentukan Key Performance Indicator (KPI) dari masing - masing perspektif yang sudah ditentukan, menentukan bobot masing - masing perspektif menggunakan Analytical Hierarchy Process (AHP), melakukan scoring system yang digunakan untuk mengetahui nilai pencapaian terhadap target masing masing perspektif, dan membuat rekomendasi perbaikan kinerja karyawan berdasarkan hasil scoring system yang sudah diperoleh.

\section{SARAN}

Bagi Akademisi

Penelitian yang akan datang bisa menjelaskan secara lebih detail terkait metode dalam scoring system yang beragam disertai tujuan penggunaan masing masing metode scoring system, karena hal ini masih menjadi keterbatasan peneliti dalam mengidentifikasi tiap metode scoring system disertai fungsi penerapannya.

\section{DAFTAR PUSTAKA}

Astuti, T. W., Praptono, B., \& Kurniawati, A. (2015). Perancangan Alat Ukur Kinerja Sumber Daya Manusia di Unit Donor Darah (UDD) PMI Kota Bandung dengan Menggunakan Metode Human Resources Scorecard. Jurnal Rekayasa Industri, 2(1), 791-801.

Becker, G. S. (1993). Human Capital: A Theoretical and Empirical Analysis With Special Reference to Education. In The University of Chicago Press (Vol. 3, Issue 92). https://doi.org/10.1093/nq/s1-IV.92.83-a 
JEMAP: Jurnal Ekonomi, Manajemen, Akuntansi, dan Perpajakan

ISSN: 2622-612X (Media Online) | Vol.3 | No.2 | Oktober 2020

Ermayanti, D. (2015). Pengukuran Kinerja Sdm Metode Human Resources Scorecard Sebagai Upaya Optimalisasi Kinerja Organisasi. Jurnal Akuntansi Dan Bisnis, 15(1), 57. https://doi.org/10.20961/jab.v15i1.176

Mardatillah, Y. (2013). Evaluasi Kinerja Manajemen Sumber Daya Manusia Pt. Bank Xyz Dengan Human Resource Scorecard. Jurnal Teknik Industri USU, 1(1), 23-27.

Maria Ulfa, M. R. (2015). Analisis Pengukuran Kinerja Karyawan Dengan Metode Human Resources Scorecard Di BMT Logam Mulia. Jurnal Ekonomi Syariah, 3(2), 311-339.

Prasetya, W. D. (2016). Pengukuran Kinerja Pegawai Dengan Menggunakan Human Resource Scorecard (Studi Pada Kantor Pelayanan Kekayaan Negara dan Lelang Manado). Jurnal Riset Bisnis Dan Manajemen, 4, 12. https://ejournal.unsrat.ac.id/index.php/jrbm/article/view/12583

Putri, D. A., \& Handayani, N. U. (2015). Pengukuran Kinerja Karyawan Pt. Pertamina (Persero) Tbbm Semarang Group Dengan Pendekatan Human Resources Scorecard. J@Ti Undip : Jurnal Teknik Industri, 10(3), 187-196. https://doi.org/10.12777/jati.10.3.187-196

Queen, F. (2019). Pengukuran Kinerja Sumber Daya Manusia Dengan Pendekatan Human Resources Scorecard. Jurnal Ilmiah Teknik Industri, 6(3), 347-351. https://doi.org/10.24912/jitiuntar.v6i3.4244

Ramadhan, D. G., Setyanto, N. W., \& Efranto, R. Y. (2017). Perancangan dan Pengukuran Kinerja Sumber Daya Manusia dengan Metode Human Resources Scorecard (HRSC) (Studi Kasus PG. Greget Baru, Bululawang). Teknik Industri, 152-162.

Rusindiyanto. (2009). Analisis Kinerja Sumber Daya Manusia Dengan Metode Human Resources Scorecard (HRSC) Studi Kasus di PT. Arto Metal Internasional Sidoarjo). Jurnal Penelitian Ilmu Teknik, 9(2), 123-129.

Sahaya, A. R., \& Wahyuni, H. C. (2017). Pengukuran Kinerja Karyawan Dengan Metode Human Resources Scorecard Dan AHP (Studi Kasus : PT. Bella Citra Mandiri Sidoarjo). Jurnal Studi Manajemen Dan Bisnis, 4(2), 137-145. https://doi.org/10.21107/jsmb.v4i2.3962 